\title{
PENENTUAN KADAR TIMBAL PADA MANISAN BUAH YANG BERKEMASAN KALENG
}

\author{
Sri Bulan Nasution \\ Jurusan Analis Poltekkes Kemenkes Medan
}

\begin{abstract}
Abstrak
Manisan buah adalah buah yang diawetkan dengan gula. Manisan buah yang kemasan kaleng dapat terkontaminasi logam berat yang berasal dari komponen kaleng. Karena pada dasarnya manisan buah bersifat asam dan akan meresap timbal dari kemasan kaleng tersebut. Kontaminasi logam berat tersebut akan berbahaya bila masuk kedalam tubuh dalam jumlah melebihi batas maksimum yang diizinkan. Akibat yang ditimbulkan logam timbal adalah gangguan sistem saraf pusat, saluran cerna dan dapat juga timbul anemia. Penelitian ini menganalisis timbal pada manisan buah berkemasan kaleng yang diperdagangkan di Irian Supermarket Aksara Medan. Populasi sampel dalam penelitian ini beberapa jenis manisan buah dan sampel yang digunakan sebanyak lima sampel buah yang berbeda.Pemeriksaan timbal pada manisan buah ini menggunakan metode kuantitatif dengan alat spektrofotometer serapan atom (SSA) yang bermerek Varian dengan panjang gelombang 217,0 $\mathrm{nm}$. Prinsip kerja dari alat spektrofotometer serapan atom adalah penambahan asam nitrat dan pemanasan yang bertujuan untuk melarutkan analit timbal dan menghilangkan zat-zat pengganggu, selanjutnya serapannya diukur dengan alat. Penelitian ini menunjukkan kadar timbal pada kelima sampel manisan buah menunjukkan kadar timbal yang berbeda. Pada manisan buah kelengkeng kadar timbalnya sebanyak $0,005 \mathrm{mg} \%$, manisan buah nenas $0,010 \mathrm{mg} \%$, manisan buah jagung $0,005 \mathrm{mg} \%$, manisan buah leci $0,014 \mathrm{mg} \%$, manisan buah rambutan $0,010 \mathrm{mg} \%$. Kadar timbal pada kelima sampel tersebut masih dalam batas maksimum yang ditetapkan oleh Badan Pengawas Obat dan Makanan Nomor HK.00.06.1.52.4011 tahun 2009. Sehingga disarankan kepada konsumen sebaiknya memperhatikan kemasan, waktu kadarluwarsa, serta pengawet yang digunakan agar tidak terjadi keracunan timbal pada makanan berkemasan kaleng.
\end{abstract}

Kata kunci : Manisan buah berkemasan kaleng, Timbal, SSA.

\section{PENDAHULUAN}

Manusia senantiasa terkena logam berat dalam lingkungan hidupnya. Di lingkungan yang kadar logam beratnya cukup tinggi, kontaminasi dalam makanan dan air dapat menyebabkan keracunan. Logam yang terlepas dari alat makan, minum dan alat masak juga dapat menimbulkan keracunan tanpa disadari (Ian tanu, 2016).

Dengan kemajuan teknologi, makanan maupun minuman dikemas secara khusus dan diawetkan supaya makanan tersebut dapat bertahan lebih lama. Biasanya tempat yang digunakan adalah kaleng, akan tetapi makanan kaleng dapat menyerap logam dari wadahnya. Pada makanan yang bersifat asam dan dikalengkan tanpa oksigen, timah menjadi anoda dalam pasangan timah-besi. Timah pada kondisi ini larut dengan laju sangat rendah dan dapat melindungi produk selama dua tahun atau bahkan lebih (Cahyadi, 2014).

Meskipun kemasan kaleng memberikan banyak keuntungan dalam pengemasan makanan, namun keamanan dan pengaruhnya terhadap makanan harus diperhatikan. Komponen logam pada kemasan kaleng dapat bermigrasi kedalam produk makanan yang dikemasnya. Migrasi tersebut dapat menimbulkan kontaminasi logam berat pada makanan yang dikemasnya. Beberapa logam berat yang dapat mengkontaminasi produk makanan kaleng, yaitu : timah (Sn), timbal $(\mathrm{Pb})$, besi $(\mathrm{Fe})$, kadmium $(\mathrm{Cd})$, dan alumunium $(\mathrm{Al})$. Sambungan antara bagian tutup kaleng dengan badan kaleng yang menggunakan timbal dapat menyebabkan cemaran timbal pada makanan kaleng. Selain itu, timah pada tinplate dapat larut kedalam produk yang dikemasnya dan mencemari produk tersebut. Serta buah yang dikemas dalam kaleng dapat terkontaminasi logam berat yang berasal dari bahan penyusun kaleng, terutama apabila kemasan kaleng tersebut sudah berkarat atau lapisan timahnya sudah terkelupas atau rusak (Vera, 2011).

Manisan merupakan salah satu produk yang mengandung kadar gula tinggi. Dengan kadar gula tinggi ini, produk manisan dapat disimpan dalam jangka waktu yang relatif lama. Manisan yang dikemas dalam kaleng dapat disimpan lebih dari setahun. Oleh karena itu pembuatan manisan juga merupakan salah satu alternatif memperpanjang daya simpan bahan 
pangan. Bahan yang diperlukan dalam pembuatan manisan terdiri atas bahan baku dan bahan tambahan. Bahan baku merupakan bahan dasar yang menjadi unsur pokok dalam membuat manisan. Bahan tambahan sering disebut pula bahan penolong yang berfungsi untuk menambah cita rasa produk, memperbaiki penampakan produk, atau pun untuk memperpanjang umur simpan produk. Setiap bahan makanan dan produk makanan olahan, cepat atau lambat akan mengalami penurunan mutu dan kerusakan atau pembusukan sehingga tidak layak untuk dikonsumsi lagi. Manisan buah pada umumnya dibedakan menjadi dua jenis yaitu manisan buah basah dan manisan buah kering. Perbedaan kedua jenis manisan tersebut terletak pada cara pembuatannya, daya awetnya, dan penampakannya atau bentuknya. Manisan basah sering dikonsumsi bersama sirup gula atau dilumuri dengan gula pekat bekas perendamannya. Sedangkan manisan kering adalah manisan yang telah direndam air gula pekat yang dikeringkan dibawah sinar matahari atau menggunakan oven pengering (Edy Soetanto, 2010).

Buah yang digunakan untuk bahan manisan buah pada dasarnya kaya akan kandungan gizi. Sayangnya, buah-buahan yang kaya akan gizi memiliki daya simpan yang sangat singkat. Dalam 2 3 hari setelah buah matang penuh, tekstur buah melunak dan mulai terjadi kerusakan. Maka kita harus mengolahnya menjadi berbagai macam olahan dan pengolahan makanan dengan cara membuat manisan buah merupakan solusi yang paling tepat. Buah musiman seperti mangga, durian, manggis, rambutan, salak, kolang-kaling, kelengkeng, buah pala, leci dan lain sebagainya, memiliki waktu produksi yang sangat terbatas sehingga kita tidak dapat memperolehnya sepanjang tahun. Dengan mengolahnya menjadi aneka olahan, kita dapat menikmatinya sewaktu-waktu tanpa perlu menunggu musimnya tiba ( Suyanti, 2010).

Buah rambutan adalah salah satu buah yang dapat diolah menjadi manisan. Buah rambutan memiliki daya simpan yang singkat maka dari itu pengolahan rambutan menjadi manisan buah merupakan salah satu alternatif yang baik dalam pemanfaatan buah yang daya simpannya tidak lama. Selain buah rambutan, buah nanas juga dapat diolah menjadi manisan buah. Buah nanas memiliki daya simpan yang singkat, jika disimpan lebih dari seminggu maka buah nanas akan menjadi busuk. Buah leci juga dapat diolah sebagai manisan buah. Buah leci dapat tumbuh di daerah tertentu saja dan merupakan buah musiman serta masa simpannya juga sangat singkat. Jagung juga banyak memiliki kegunaan diantaranya sebagai bahan pangan, pakan ternak, dan bahan baku industri. Jagung merupakan tanaman berakar serabut dan termasuk buah musiman yang masa penyimpanannya pun juga sangat singkat. Selain itu sekarang jagung sudah dapat kita temukan dalam kemasan yang juga dapat digunakan sebagai sayur dalam masakan. Kelengkeng atau lengkeng termasuk buah yang sangat disukai di indonesia. Rasanya manis dan menyegarkan, buah ini banyak mengandung sukrosa, glukosa, protein, lemak, asam, yang berguna untuk meningkatkan stamina sehabis sakit, dan sangat baik untuk memenuhi kebutuhan energi. Seperti buah rambutan, nanas, leci, dan jagung, kelengkeng juga merupakan buah musiman yang memiliki daya simpan yang singkat. Tetapi perlu kita ketahui, bahwa manisan buah bersifat asam yang bila disimpan dalam kemasan kaleng maka akan meresap logam timbal dari kemasan kaleng tersebut. Jika kita mengkonsumsi manisan buah yang telah terkontaminasi oleh logam timbal maka secara bersamaan logam timbal akan masuk kedalam tubuh dalam paparan yang melewati batas dan hal itu akan berakibat fatal bagi kesehatan.

Timbal atau dalam keseharian lebih dikenal dengan nama timah hitam, dalam bahasa ilmiahnya dinamakan plumbum, dan logam ini disimbolkan dengan $\mathrm{Pb}$. Logam ini termasuk kedalam kelompok logam-logam golongan IV-A pada Tabel Periodik unsur kimia. Mempunyai nomor atom (NA) 82 dengan bobot atau berat atom (BA) 207,2 (Heryando Palar, 2016).

Timbal $(\mathrm{Pb})$ dapat menyebabkan keracunan kronik dan akut. Keracunan kronik dapat terjadi melalui mulut, absorpsi melalui kulit, dan menghirup partikel timbal atau senyawa timbal organik. Gejala yang timbul mula-mula nafsu makan berkurang, berat badan menurun, kadang-kadang muntah-muntah, lelah, sakit kepala, badan lemah, dan dapat mengakibatkan anemia. Sedangkan, Keracunan akut yang artinya keracunan yang terjadi biasanya disebabkan oleh masuknya senyawa $\mathrm{Pb}$ yang larut dalam asam atau inhalasi uap $\mathrm{Pb}$ yang menimbulkan rasa haus dan rasa logam. Gejala yang timbul berupa mual, muntah, sakit perut hebat, kelainan fungsi otak, anemia berat, kerusakan ginjal, bahkan kematian dapat terjadi dalam waktu 1-2 hari. Absorpsi $\mathrm{Pb}$ terutama melalui saluran cerna dan saluran napas. Absorpsi melalui usus pada orang dewasa kira-kira $10 \%$, pada anak kira-kira $40 \%$. Kira-kira $90 \%$ partikel $\mathrm{Pb}$ di udara diabsorpsi melalui saluran napas (Ian tanu, 2016).

Batas paparan untuk timbal dan timbal arsenat di udara $0,15 \mathrm{mg} / \mathrm{meter}$ kubik. Sedangkan batas paparan untuk timbal tetrametil dan timbal tetraetil 0,07 mg/meter kubik. Batas kandungan timbal dalam makanan 2,56 mg/kg (Sartono, 2012).

Menurut Badan Pengawasan Obat dan Makanan Republik Indonesia, batas maksimum kadar timbal yang diperbolehkan pada buah olahan dan sayur olahan ialah 0,5 ppm ( BPOM, 2009).

Kasus keracunan makanan bukan hal yang asing bagi kita. Menurut Zulkifli Apt selaku Kepala Balai Pengawasan Obat dan makanan (BPOM) Bengkulu mengungkapkan kasus keracunan makanan selama tahun 2012, mengalami peningkatan jika dibandingkan dengan tahun-tahun sebelumnya. Pada tahun 2011 jumlah kasus keracunan tercatat 294 kasus Toksiko dan 6 kasus Keracunan Luar Biasa, kemudian pada tahun 2016 kasus keracunan sangat tinggi mencapai 509 Toksiko dan 2 kasus Keracunan Luar Biasa, tahun 2015 sebanyak 423 Toksiko dan 1 kasus Keracunan Luar Biasa, serta tahun 2014 sebanyak 229 
kasus dan 2014 diketahui 3 kasus Keracunan Luar Biasa (http://bengkuluekspress.com/300-kasuskeracunan).

Dari beberapa penelitian yang telah dilakukan di Amerika Serikat, disimpulkan bahwa pemasukan $\mathrm{Pb}$ sehari-hari ke dalam tubuh dan digolongkan pada tingkat keterpaparan normal adalah dalam kisaran 330 ug perhari, dengan tingkatan variasi antara 100 ug sampai dengan 2000 ug ( Heryando Palar, 2016).

Berdasarkan latar belakang di atas maka peneliti tertarik melakukan penelitian untuk mengetahui apakah ada kandungan timbal pada manisan buah yang berkemasan kaleng.

\section{METODE}

Jenis dan desain penelitian yang digunakan di dalam penelitian ini adalah penelitian survey yang bersifat deskriptif yang bertujuan untuk mengetahui apakah ada terdapat kandungan timbal pada manisan buah yang berkemasan kaleng yang diperdagangkan di Irian supermarket aksara Medan.

Lokasi penelitian dilakukan di Balai Laboratorium Kesehatan Medan yang dilakukan mulai dari pengumpulan data dilapangan mulai bulan September 2018

Dalam penelitian ini yang menjadi populasi adalah sebanyak 5 jenis manisan buah di Irian Supermarket Aksara Medan, dan diketahui dari survey awal di bulan Agustus 2018 dengan sampel penelitian ini adalah manisan buah yang berkemasan kaleng yang diperdagangkan di Irian Pasar Swalayan Aksara Medan, sebanyak 5 sampel buah yang berbeda.

Jenis pengumpulan data yang dilakukan dengan data primer. Dalam penelitian ini data diperoleh melalui observasi dan melakukan pemeriksaan secara kuantitatif.

\section{HASIL}

Dari analisa kadar timbal $(\mathrm{Pb})$ pada 5 sampel Manisan buah yang berkemasan kaleng diperoleh hasil sebagai berikut :

\section{Tabel 1. Data pembacaan pada AAS ( $\mathrm{ppm}$ )}

\begin{tabular}{lcccc} 
No & $\begin{array}{c}\text { Nama } \\
\text { Sampel }\end{array}$ & $\begin{array}{c}\text { Berat } \\
\text { Sampel } \\
(\mathbf{G r a m})\end{array}$ & $\begin{array}{c}\text { Pembacaan } \\
(\mathbf{p p m})\end{array}$ & $\begin{array}{c}\text { Panjang } \\
\text { Gelombang } \\
(\mathbf{n m})\end{array}$ \\
\hline 1 & $\begin{array}{c}\text { Manisan } \\
\text { Kelengkeng }\end{array}$ & 20,0673 & 0,01 & 217 \\
2 & $\begin{array}{c}\text { Manisan } \\
\text { Nanas }\end{array}$ & $\begin{array}{c}20, \\
8013\end{array}$ & 0,02 & 217 \\
& $\begin{array}{c}\text { Manisan } \\
\text { Jagung }\end{array}$ & 20,2445 & 0,01 & 217 \\
4 & $\begin{array}{c}\text { Manisan Leci } \\
\text { Manisan }\end{array}$ & 20,4305 & 0,03 & 217 \\
5 & 20,0990 & 0,02 & 217 \\
\hline
\end{tabular}

Tabel 2. Kadar Pb pada Manisan Buah

\begin{tabular}{ccc}
\hline No & Nama Sampel & $\begin{array}{c}\text { Kadar Timbal } \\
(\mathbf{m g} \%)\end{array}$ \\
\hline 1 & Manisan Kelengkeng & 0,005
\end{tabular}

\begin{tabular}{lll}
2 & Manisan Nanas & 0,010 \\
3 & Manisan Jagung & 0,005 \\
4 & Manisan Leci & 0,014 \\
5 & Manisan Rambutan & 0,010 \\
\hline
\end{tabular}

Dari hasil penelitian yang dilakukan terhadap kadar timbal $(\mathrm{Pb})$ pada 5 sampel manisan buah diperoleh hasil yang hampir sama yaitu pada sampel No 1 yaitu manisan buah kelengkeng dengan kadar timbal 0,005 mg\%, sampel No 2 yaitu manisan buah nanas dengan kadar timbal 0,010 mg\%, sampel No 3 yaitu manisan buah jagung dengan kadar timbal 0,005 mg\%, sampel No 4 yaitu manisan buah leci dengan kadar timbal sekitar 0,014 mg\%, dan sampel No 5 yaitu manisan buah rambutan dengan kadar 0,010 mg\%.

Hasil yang tertinggi ialah $0,014 \mathrm{mg} \%$ pada manisan buah leci, karena pada manisan buah tersebut yang banyak mengandung logam timbal. Adanya logam timbal pada manisan buah kaleng tersebut berasal dari komponen logam pada kemasan kaleng yang dapat bermigrasi kedalam produk makanan yang dikemasnya serta buah yang dikemasnya dalam kaleng dapat terkontaminasi yang berasal dari bahan penyusun kaleng, terutama apabila kemasan kaleng tersebut sudah berkarat dan manisan buah buah bersifat asam yang dapat menyerap logam timbal dari kemasannya.

\section{KESIMPULAN}

1. Dari hasil penelitian yang dilakukan terhadap 5 sampel manisan buah yang berkemasan kaleng dengan tiga merek yang berbeda diperoleh kadar $\mathrm{Pb}$ yang berbeda pada kelima manisan buah.

2. Setelah dianalisa pada ke 5 sampel tersebut menunjukkan bahwa ke 5 sampel tersebut masih dalam batas yang diperbolehkan sesuai dengan ketetapan SNI yaitu 0,5 ppm.

\section{SARAN}

Bagi konsumen sebaiknya berhati - hati dalam mengkonsumsi manisan buah yang berkemasan kaleng, konsumen hendaknya memperhatikan kemasan kaleng yang tidak cacat, waktu kadarluwarsa, serta jenis buah dari manisan tersebut. Hal ini disebabkan karena manisan buah yang berkemasan kaleng bersifat asam yang dapat melarutkan logam timbal dari kemasan kaleng.

\section{DAFTAR PUSTAKA}

Cahyadi, W, 2014, "Bahaya Pencemaran Timbal pada Makanan dan Minuman", Fakultas Teknik Unpas Departemen Farmasi Pascasarjana ITB, www.pikiranrakyat.com/cetak/0804/19/cakrawala/utama1.ht $\underline{\mathrm{m}-19 \mathrm{k}}$.

Palar Heryando, 2016, "Pencemaran \& Toksikologi Logam Berat Cetakan ke empat", Penerbit Rineka Cipta, Anggota IKAPI, Jakarta.

Sartono, 2012, “ Racun \& Keracunan”, Penerbit Widya Medika, Jakarta. 
Tanu Ian, 2017, “ Farmakologi dan Farmasi, Edisi kelima", Penerbit Gaya Baru, Jakarta.

Vera, 2011, “ Jurnal analisis logam timbal $(\mathrm{Pb})$, timah $(\mathrm{Sn})$, dan kadmium $(\mathrm{Cd})$ dalam buah lengkeng kemasan keleng secara spektrofotometri serapan atom", Program studi Farmasi, Universitas
Indonesia.

Http://lontar.ui.ac.id/file?file=digital/20290776S950-Analisis\%20logam. pdf )

Zulkifli, 2012, "Kasus Keracunan Makanan menurut BPOM” http://bengkuluekspress.com/300kasus-keracunan). 